\title{
Penerapan Model Pembelajaran Inkuiri Terbimbing Untuk Meningkatkan Keterampilan Proses Sains Peserta Didik Pada Pembelajaran IPA Materi Pokok Cahaya dan Alat Optik Kelas VIIIA SMP Negeri 1 Wawoni Utara
}

\author{
Asdianti $^{1)}$, La Tahang ${ }^{2)}$, Luh Sukariasih ${ }^{2)}$ \\ ${ }^{1}$ Alumni Jurusan Pendidikan Fisika, Universitas Halu Oleo, Jl. H.E.A Mokodompit, Kendari 93232 \\ ${ }^{2}$ Dosen Jurusan Pendidikan Fisika, Universitas Halu Oleo, Jl. H.E.A Mokodompit, Kendari 93232 \\ Email : mikyasdian@gmail.com
}

\begin{abstract}
This study aims to: 1) To describe the science process skills improvement classes learners VIIIA of SMP Negeri 1 North Wawonii taught through guided inquiry learning model; 2) Describe the activities of teachers in science teaching VIIIA grade SMP Negeri 1 North Wawonii on poko material light and an optical instrument with use taught guided inquiry learning model.This type of research is the Classroom Action Research (CAR), which has been conducted in two cycles. Subjects in this study were all learners VIIIA grade SMP Negeri 1 North Wawonii 2018/2019 school year totaling 19 people. The data collected in this study is the science process skills gained from the observation sheet. Data analysis was performed descriptive statistics. From the results of data analysis obtained by valueAverage science process skills of students in the first cycle of 2.3 included in the category enough and for the average value of the activities of teachers in the first cycle is the second cycle 2,9.Padaearned valueAverage science process skills of students in the first cycle of 3.6 included in both categories, and for the average value of teacher activity in the second cycle is 3.61.Based on the results of research and discussion concluded that the science learning in the subject matter of the Light and Optics are taught using guided inquiry learning model has increased in the science process skills and activities of teachers.
\end{abstract}

Keywords: Science process skills; Guided inquiry learning model.

Abstrak: Penelitian ini bertujuan untuk: 1) Untuk mendeskripsikan peningkatan keterampilan proses sains peserta didik kelas VIII ${ }_{\mathrm{A}}$ SMP Negeri 1 Wawonii Utara yang diajarkan melalui model pembelajaran inkuiri terbimbing; 2) Mendeskripsikan aktivitas guru pada pembelajaran IPA kelas VIII $_{\mathrm{A}}$ SMP Negeri 1 Wawonii Utara pada materi pokok cahaya dan alat optik yang diajarkan dengan menggunakan model pembelajaran inkuiri terbimbing. Jenis penelitian ini adalah Penelitian Tindakan Kelas (PTK) yang telah dilaksanakan dalam dua siklus. Subjek dalam penelitian ini adalah seluruh peserta didik kelas VIII $_{\mathrm{A}}$ SMP Negeri 1 Wawonii Utara tahun ajaran 2018/2019 yang berjumlah 19 orang. Data yang dikumpulkan pada penelitian ini adalah keterampilan proses sains yang diperoleh dari lembar observasi. Analisis data yang dilakukan statistik deskriptif. Dari hasil analisis data diperoleh nilai rata-rata keterampilan proses sains peserta didik di siklus I sebesar 2,5 termasuk dalam kategori cukup dan untuk nilai rata-rata aktivitas guru pada siklus I yaitu 2,9. Pada siklus II diperoleh nilai rata-rata keterampilan proses sains peserta didik di siklus II sebesar 3 termasuk dalam kategori baik, dan untuk nilai rata-rata aktivitas guru pada siklus II yaitu 3,61.Berdasarkan hasil penelitian dan pembahasan dapat disimpulkan bahwa pembelajaran IPA pada materi pokok Cahaya dan Alat Optik yang diajar menggunakan model pembelajaran inkuiri terbimbing mengalami peningkatan pada keterampilan proses sains dan aktivitas guru.

Kata Kunci: Keterampilan proses sains; Model pembelajaran inkuiri terbimbing.

\section{PENDAHULUAN}

Salah satu masalah yang ada di SMP Negeri 1 Wawonii Utara adalah kurang maksimalnya guru dalam membawakan materi, kurangnya fasilitas pembelajaran yang ada di sekolah dan kurangnya motivasi peserta didik untuk belajar 
sehingga proses belajar mengajar berjalan kurang efektif dan nilai siswa rendah. Berdasarkan hasil wawancara yang dilakukan kepada beberapa peserta didik di SMP Negeri1 Wawonii Utara tanggal 19 Febuari 2019, salah satu mata pelajaran yang sulit dipahami adalah mata pelajaran IPA. Beberapa peserta didik memiliki motivasi belajar yang rendah untuk mengikuti pelajaran IPA. Hal ini disebabkan para peserta didik memiliki kesulitan dalam memahami konsep dan menghafal banyaknya rumus yang rumit dan membingungkan. Terlebih lagi dalam materi pokok cahaya dan alat optik guru hanya memberikan gambaran-gambaran kepada peserta didik tanpa melakukan praktek secara langsung, sehingga membuat peserta didik cenderung hanya bisa menghafal tanpa memahami konsep dalam pelajaran. Hal ini juga membuat peserta didik kurang terampil dalam menuangkan ide-ide yang dimilikinya sehingga proses belajar mengajar diruangan cenderung pasif dan kurang terkesan bagi peserta didik. Dimana IPA merupakan salah satu mata pelajaran disekolah dinilai cukup memegang peranan penting dalam meningkatkan pengetahuan peserta didik untuk berpikir kritis karena IPA merupakan salah satu sarana berpikir untuk mengkaji sesuatu secara logis dan sistematis, sehingga dipandang penting agar IPA dikuasai dengan baik oleh para peserta didik. Hal ini diduga menjadi salah satu faktor penyebab rendahnya pemahaman materi pelajaran IPA pada materi pokok cahaya dan alat optik peserta didik SMP Negeri 1 Wawonii Utara.

Untuk mengatasi masalah tersebut salah satu solusinya adalah penggunaan model pembelajaran inkuiri terbimbing. Penggunaan solusi ini akan dilaksanakan pada dua siklus pembelajaran di kelas, dimana setiap siklus akan diterapkan model pembelajaran inkuiri terbimbing untuk meningkatkan keterampilan proses sains peserta didik. Model pempelajaran inkuiri terbimbing yaitu model yang lebih menekankan pada peserta didik untuk aktif melatih keberanian, berkomunikasi dan berusaha menemukan pengetahuannya sendiri untuk memecahkan permasalahan yang dihadapi melalui suatu percobaan dengan bimbingan langsung oleh guru.

Cahaya dan alat optik merupakan salah satu topik yang menarik untuk dipelajari siswa, karena cahaya merupakan fenomena/gejala alam yang terjadi disekitar siswa. siswa dapat melihat benda yang ada disekitar dan benda yang ada dibelakang mereka dengan menggunakan cermin. Kita bisa melihat suatu benda karena benda tersebut dikenai cahaya kemudian dipantulkan ke mata, sifat-sifat cahaya menimbulkan bermacam pengertian dan pemahaman yang berbeda dalam pikiran peserta didik, dalam mengamati materi sifat-sifat cahaya peserta didik dituntut untuk dapat mengamati gejala-gejala alam yang berkaitan dengan cahaya dan dapat menjelaskan mengapa gejala-gejala alam tersebut terjadi. Berdasarkan hal tersebut, peneliti memilih materi cahaya dan alat optik untuk dijadikan objek penelitian pada peserta didik kelas VIII $_{\mathrm{A}}$ SMP Negeri 1Wawonii Utara.

Inkuiri dapat didefinisikan sebagai suatu pencarian kebenaran, infomasi atau pengetahuan. Sagala (2007), mengemukakan inkuiri merupakan pendekatan pembelajaran yang dapat diterapkan pada semua jenjang pendidikan. Pembelajaran degan pendekatan ini sangat terintegrasi meliputi penerapan proses sains dengan proses berpikir logis dan berpikir kritis. inkuiri merupakan pendekatan untuk memperoleh pengetahuan dan memahami jalan bertanya, observasi, investigasi, analisis, dan evaluasi. (Made, 2012).

Inkuiri terbimbing dengan tahap-tahap pembelajaranya mampu melatih peserta didik dalam meningkatkan keterampilan inkuiri (Wulanningsih dan prayitno, 2012). Sintaks pembelajaran inkuiri menurut Triyanto (2007) yaitu terdiri dari menyajikan masalah, membuat hipotesis, merancang percobaan, melakukan percobaan, menganalisis data, dan membuat kesimpulan. Dari sintaks pembelajaran inkuiri 
tersebut memiliki potensi yang bermanfaat dalam meningkatkan keterampian proses sains. Hal ini di dukung oleh Zehra dan nermin (2009) yang menyatakan bahwa inkuiri terbimbing mampu meningkatkan keterampilan proses sains. Prosedur pembelajaran inkuiri dilakukan dengan melibatkan siswa dalam penyelidikan, membantu siswa mengidentifikasi konsep atau metode, dan mendorong siswa menemukan cara untuk memecahkan masalah yang dihadapi. Guru berperan dalam memberikan masalah dan membimbing kegiatan pemecahan masalah (Amri dan Ahmadi, 2010).

Menurut Rustam (2005) mengatakan bahwa keterampilan proses sains adalah keterampilan pembelajaran yang berorientasi kepada proses IPA. Keterampilan proses sains melibatkan keterampilan kognitif/intelektual, fisik dan sosial. Dimyanti dan Mudjiyono (2002) menerangkan mengenai manfaat keterampilan proses sains yaitu: pertama, ilmu pengetahuan peserta didik dapat berkembang dengan pendekatan keterampilan proses, peserta didik dapat mengalami rangsangan ilmu pengetahuan dan dapat lebih baik mengerti fakta serta konsep ilmu pengetahuan. Kedua, pembelajaran keterampilan proses sains akan memberikan kesempatan kepada peserta didik untuk bekerja dengan ilmu pengetahuan. Ketika ketermpilan proses sains dapat digunakan oleh peserta didik untuk belajar proses dan sekaligus produk ilmu pengetahuan.

Beberapa hasil penelitian menunjukkan kelebihan inkuiri dalam pembelajaran sains. Penelitian oleh Hussain dan Shakoor (2011) menyatakan bahwa pembelajaran fisika dengan inkuiri secara signifikan memberikan hasil belajar lebih baik bila dibandingkan dengan pembelajaran konvensional. Sikap ilmiah dan hasil belajar siswa menunjukkan peningkatan yang lebih baik dengan model inkuiri terbimbing dari pada kelompok siswa yang belajar dengan pembelajaran konvensional (Dewi dkk., 2013). Pembelajaran dengan model inkuiri terbimbing dapat meningkatka aktivitas dan kreativitas belajar siswa yang nantinya berdampak pada hasil belajar (A'yunin dkk., 2016). Kesulitan belajar siswa pada pokok bahasan cahaya dapat diatasi dengan pembelajaran inkuiri terbimbing yang berdampak pada peningkatan hasil belajar (Wijayanti dkk., 2010). Pembelajaran dengan model inkuiri terbimbing mampu memotivasi siswa dalam proses pembelajaran sehingga mampu menguasai materi yang diajarkan (Winetacahya dkk, 2014). Oleh karena itu penerapan model inkuiri terbimbing dapat dijadikan salah satu model pembelajaran untuk dapat meningkatkan pemahaman konsep siswa. Lebih lanjut pula hasil penelitian Pullaila (2007) membuktikan bahwa pembelajaran inkuiri terbimbing mampu meningkatkan kemampuan berpikir kreatif siswa secara signifikan untuk kelima indikator keterampilan berpikir kreatif, serta hasil penelitian Ridwan (2006) tentang model pembelajaran inkuiri mampu meningkatkan pemahaman konsep, keterampilan proses sains dan keterampilan ilmiah serta keterampilan ilmiah siswa. Beberapa hasil penelitian di atas menunjukkan bahwa pembelajaran inkuiri mampu mengaktifkan siswa, dengan menggunakan proses pembelajaran inkuiri siswa dapat belajar berdasarkan pengalaman, sehingga dapat meningkatkan pemahaman konsep dan keterampilan ilmiah siswa.

Berdasarkan uraian di atas, maka perlu dilakukan suatu penelitian dengan judul Penerapan Model Pembelajaran Inkuiri Terbimbing untuk Meningkatkan Keterampilan Proses Sains Peserta Didik pada Pembelajaran IPA Materi Pokok Cahaya dan Alat Optik Kelas VIII $_{A}$ SMP Negeri 1 Wawonii Utara.

\section{METODE}

Jenis penelitian ini adalah penelitian tindakan kelas dengan menerapkan model pembelajaran inkuiri terbimbing untuk meningkatkan keterampilan proses sains peserta didik pada pembelajaran IPA materi pokok Cahaya dan Alat Optik kelas VIII A SMP Negeri 
1 Wawonii Utara. Penelitian ini telah dilaksanakan pada semester genap tahun ajaran 2018/2019 di kelas VIII $_{\text {A }}$ SMP Negeri 1 Wawonii Utara pada materi pokok Cahaya dan Alat Optik. Subjek dalam penelitian ini adalah

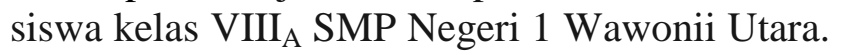
yang terdaftar pada tahun ajaran 2018/2019 dengan jumlah siswa 19 orang yang terdiri dari 10 orang laki-laki dan 9 orang perempuan.

\section{Faktor yang Diteliti}

Faktor-faktor yang diteliti dalam penelitian tindakan kelas ini adalah:

1.Faktor siswa: untuk melihat aktivitas siswa selama pembelajaran berlangsung, peningkatan keterampilan proses sains dalam mempelajari pelajaran IPApada materi Cahaya dan Alat
Optik, yang diajarkan menggunakan model pembelajaran pembelajaran inkuiri terbimbing.

2.Keterampilan proses sains: yang diteliti yaitu keterampilan proses sains kelas VIII $_{\mathrm{A}}$ SMP Negeri 1 Wawonii Utara, pada setiap siklus tindakan yang dilakukan oleh guru dalam proses pembelajaran dengan menggunakan model pembelajaran inkuiri terbimbing.

\section{Desain Penelitian}

Desain Penelitian yang akan digunakan dalam penelitianyaitu model siklus (cycle). Model siklus ini berbentuk siklus yang meliputi model pembelajaran, pelaksanaan (action), observasi (observe) dan refleksi (reflect). Adapun prosedur pelaksanaan tindakan kelas dalam penelitian ini, dapat disajikan melalui gambar berikut;

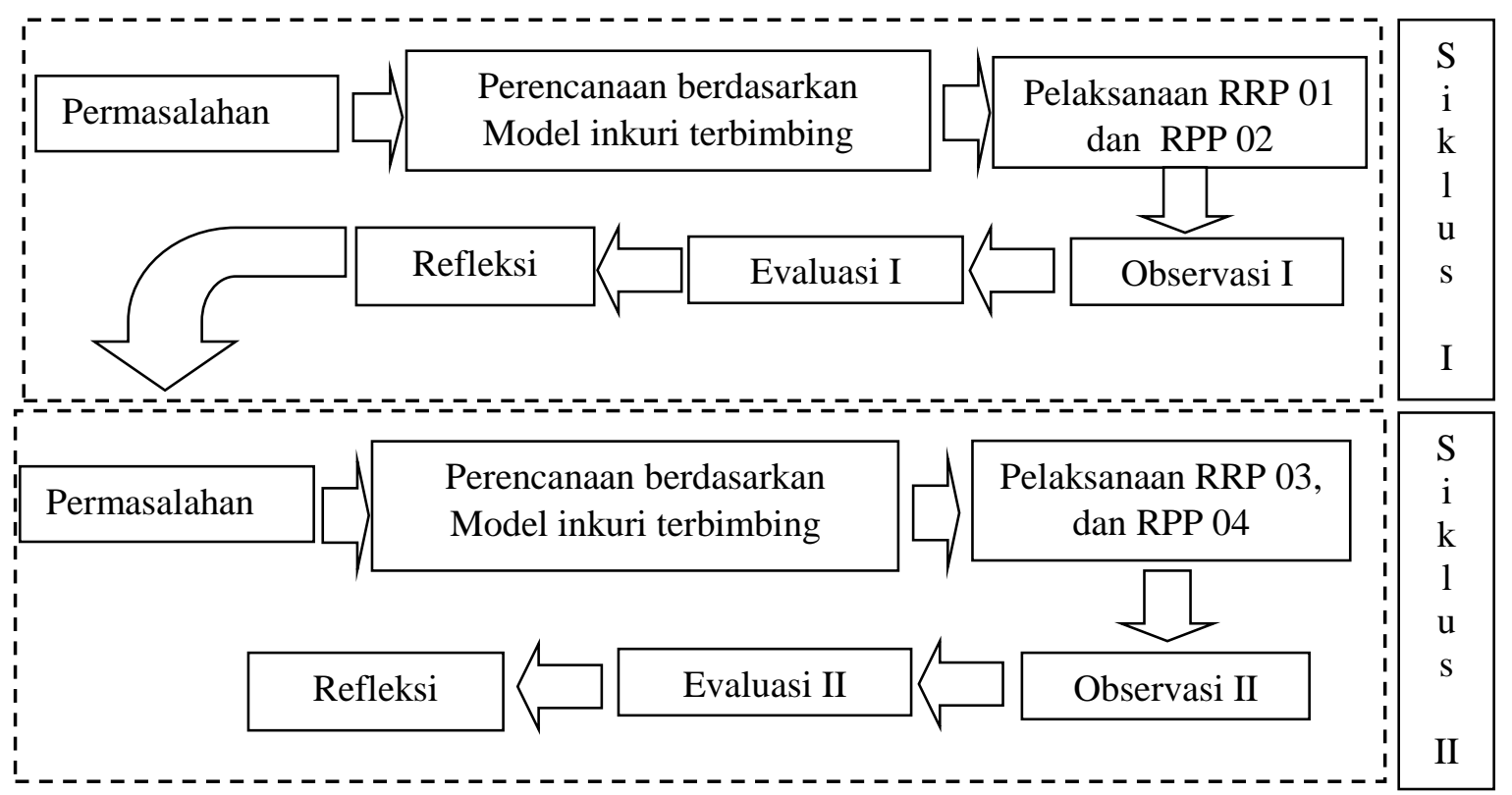

Gambar 1. Rancangan dan Desain Penelitian Tindakan Kelas

\section{Instrumen Penelitian}

Untuk memperoleh yang dibutuhkan, digunakan teknik pengumpulan berikut;

1. Observasi, yaitu peneliti menyediakan lembar observasi untuk memperoleh data tentang aktivitas guru dan aktivitas serta keterampilan proses sains siswa selama proses pembelajaran berlangsung.
2. Lembar observasi keterampilan proses sains peserta didik. Lembar observasi keterlaksanaan model guru indikatornya disusun sesuai dengan aspek belajar mengajar di dalam kelas yang sesuai dengan tahap-tahap model pembelajaran inkuiri terbimbing. Untuk lembar observasi keterampilan proses sains peserta didik 
disusun dalam 7 aspek penilaian yang terdiri atas mengobservasi, merumuskan masalah, merencanakan penelitian atau eksperimen, menginterpretasikan data, menerapkan konsep dan prinsip, menyimpulkan dan mengkomun nikasikan

Teknik Pengumpulan Data dan Analisis Data

Teknik analisis data yang digunakan berupa analisis deskriptif yang dimaksudkan untuk memberikkan gambaran distribusi keterampilan proses sains yang diajar dengan menggunakan model pembelajaran inkuiri tebimbing.

Langkah-langkah analisis data adalah;

1. Keterampilan Proses Sains (KPS) Peserta

Didik

Memberikan skor berdasarkan pedoman penskoran terhadap setiap pelaksanaan KPS kepada peserta didik berdasarkan kriteria yang telah ditentukan. Kemudian menghitung presentase jumlah skor perolehan KPS kelompok peserta didik mengacu pada rumus berikut.

Presentase perolehan

$=\frac{\text { Jumlah skor yang diperoleh }}{\text { Jumlah skor Maksimal }} \times 100 \%$

2. Aktivitas Guru

Tabel 1. Skor Rata-rata Keterampilan Proses Sains Peserta didik Pada Siklus I dan Silkus II

\begin{tabular}{|l|l|c|c|c|c|}
\hline \multirow{2}{*}{ No } & \multirow{2}{*}{ Aspek-aspek yang diamati } & \multicolumn{3}{|c|}{ Skor rata-rata keterampilan poses sains } \\
\cline { 3 - 6 } & & Siklus I & Kategori & Siklus II & Kategori \\
\hline 1 & Observasi (Mengamati) & 22, & Cukup & 2,7 & Cukup \\
\hline 2 & Merumuskan masalah & 2,4 & Cukup & 2,8 & Cukup \\
\hline 3 & Merumuskan hipotesis & 2.5 & Cukup & 2,8 & Cukup \\
\hline 4 & Melakukan Percobaan/ Kegiatan Diskusi & 2,5 & Cukup & 2,9 & Cukup \\
\hline 5 & Menganalisis Data & 2,6 & Cukup & 3.1 & Baik \\
\hline 6 & Menyimpulkan danMengkomunikasikan & 2,8 & Cukup & 3,4 & Baik \\
\hline \multicolumn{2}{|l|}{ Jumlahy } & 15 & & 17,7 & \\
\hline \multicolumn{2}{|l|}{ Rata-rata } & 2,5 & Cukup & 3 & Baik \\
\hline
\end{tabular}

Dari tabel 1 tersebut, menunjukkan adanya peningkatan KPS peserta didik dari siklus I ke siklus II, dimana nilai rata-rata KPS
Menurut Purwanto (2010) dalam menentukan analisis data lembar observasi aktivitas guru selama kegiatan belajar mengajar sebagai berikut.

Analisis data lembar observasi aktivitas guru dalam kegiatan belajar mengajar dengan menggunakan rumus:

$$
\text { Rata }- \text { rata }=\frac{\sum \text { skoritem }}{\sum \text { item }} \times 100 \%
$$

\section{HASIL DAN PEMBAHASAN}

Keterampilan proses sains

Data keterampilan proses sains peserta didik kelas VIII $_{\mathrm{A}}$ SMP Negeri 1 Wawonii Utara setelah melakukan kegiatan pembelajaran dengan model pembelajaran Inkuiri Terbimbing diperoleh menggunakan lembar observasi keterampilan proses sains dengan cara observer memberikan skor pada setiap aspek keterampilan proses sains yang dilakukan oleh peserta didik sesuai dengan kriteria yang telah ditentukan dalam pedoman penskoran. Siklus I terdiri dari dua kali pertemuan dan siklus II terdiri dari dua kali pertemuan. Data skor ratarata keterampilan proses sains peserta didik dalam proses belajar-mengajar pada setiap siklus dapat dilihat pada Tabel 1. peserta didikpada siklus I sebesar 2,5 mengalami peningkatan pada siklus II menjadi 3 . 
Keterlaksanaan Model Pembelajaran Inkuiri Terbimbing

Aktivitas guru dalam melaksanakan kegiatan pembelajaran dengan menggunakan model pembelajaran inkuiri terbimbing pada materi pokok cahaya dan alat optik diperoleh melalui penilaian guru IPA SMP Negeri 1 Wawanii Utara (observer) pada aktivitas peneliti dalam mengajar menggunakan lembar observasi aktivitas guru. Analisis data aktivitas guru dapat dilihat pada Tabel 2.

Tabel 2. Data Skor Rata-rata Kerlaksanaan Model Pembelajaran Inkuiri Terbimbing pada Setiap Siklus.

\begin{tabular}{|c|c|c|c|c|c|}
\hline \multirow[b]{2}{*}{ No } & \multirow[b]{2}{*}{ Aspek yang Diamati } & \multicolumn{4}{|c|}{ SKOR AKTIVITAS } \\
\hline & & SIKLUS I & 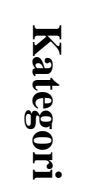 & SIKLUS II & 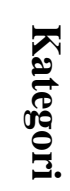 \\
\hline \multirow{6}{*}{ I } & A. Pendahuluan & & & & \\
\hline & $\begin{array}{l}\text { 1. mengucapkan salam dan berdoa sebelum memulai } \\
\text { pelajaran }\end{array}$ & 4 & SB & 4 & SB \\
\hline & $\begin{array}{l}\text { 2. mengecek kondisi ruangan, kehadiran peserta } \\
\text { didik dan berdoa bersama }\end{array}$ & 4 & SB & 4 & SB \\
\hline & $\begin{array}{l}\text { 3. memberikan apersepsi kepada peserta didik dan } \\
\text { memotivasi peserta didik }\end{array}$ & 4 & SB & 4 & $\mathrm{SB}$ \\
\hline & 4. Menyampaikan tujuan pembelajaran & 4 & SB & 4 & SB \\
\hline & \multicolumn{5}{|l|}{ B. Kegiatan Inti } \\
\hline \multirow{10}{*}{ II } & \multicolumn{5}{|c|}{ Merumuskan Masalah } \\
\hline & $\begin{array}{l}\text { 5. Guru membagi peserta didik dalam beberapa } \\
\text { kelompok yang terdiri atas } 4 \text { kelompok orang } \\
\text { dalam masing-masing kelompok }\end{array}$ & 3 & B & 4 & SB \\
\hline & $\begin{array}{l}\text { 6. Guru mengarahkan peserta didik berdiskusi untuk } \\
\text { merumuskan masalah }\end{array}$ & 2 & $\mathrm{C}$ & 3 & B \\
\hline & $\begin{array}{l}\text { 7. Guru membagikan LKPD dan } \\
\text { tentang tugas yang akan dikerjakan }\end{array}$ & 3 & B & 4 & SB \\
\hline & \multicolumn{5}{|c|}{ Merumuskan Hipotesis } \\
\hline & $\begin{array}{l}\text { 8. Guru mengarahkan peserta didik saling bertanya } \\
\text { jawab untuk Merumuskan Hipotesis }\end{array}$ & 3 & B & 4 & SB \\
\hline & $\begin{array}{l}\text { 9. Menulis setiap jawaban dari pertanyaan yang } \\
\text { timbul oleh peserta didik di papan tulis, } \\
\text { mengarahkan peserta didik memilih salah satu } \\
\text { jawaban yang dijadikan hipotesis }\end{array}$ & 2,5 & $\mathrm{C}$ & 4 & SB \\
\hline & \multicolumn{5}{|c|}{ Mengumpulkan Data } \\
\hline & $\begin{array}{l}\text { 10. Mengarahkan peserta didik untuk mempersiapkan } \\
\text { alat dan bahan }\end{array}$ & 2 & $\mathrm{C}$ & 3 & B \\
\hline & $\begin{array}{l}\text { 11. Mengarahkan peserta didik untuk melakukan } \\
\text { percobaan sesuai LKPD }\end{array}$ & 2 & $\mathrm{C}$ & 3 & B \\
\hline
\end{tabular}




\begin{tabular}{|c|c|c|c|c|c|}
\hline & $\begin{array}{l}\text { 12. Membimbing dan mengarahkan peserta didik agar } \\
\text { mengumpulkan data yang tepat sesuai dengan } \\
\text { percobaan }\end{array}$ & 3 & $\mathrm{~B}$ & 3.50 & $\mathrm{~B}$ \\
\hline & Menguji Hipotes & & & & \\
\hline & $\begin{array}{l}\text { 13. Mengarahkan peserta didik saat menganalisis data } \\
\text { hasil percobaan }\end{array}$ & 2,5 & $\mathrm{C}$ & 3 & B \\
\hline & $\begin{array}{l}\text { 14. Mengawasi dan membimbing peserta didik saa } \\
\text { tmenganalisis data hasil percobaan }\end{array}$ & 2 & $\mathrm{C}$ & 3,50 & B \\
\hline & $\begin{array}{l}\text { 15. Mengarahkan peserta didik untuk memeriksa hasil } \\
\text { percobaan dengan hipotesis yang telah dibuat }\end{array}$ & 2 & $\mathrm{C}$ & 3,5 & B \\
\hline & $\begin{array}{l}\text { 16. Mengawasi, memberikan arahan dan bimbingan } \\
\text { agar peserta didik dapat mengaitkan temuan } \\
\text { alternatif dengan hasil pengololaan data }\end{array}$ & 2 & $\mathrm{C}$ & 3 & B \\
\hline & Merumuskan Kesim & & & & \\
\hline & $\begin{array}{l}\text { 17. Mengarahkan dan membimbing peserta didik dari } \\
\text { menyimpulkan hasil percobaan masing-masing } \\
\text { kelompok }\end{array}$ & 2 & $\mathrm{C}$ & 3 & B \\
\hline & $\begin{array}{l}\text { 18. Meminta peserta didik menjelaskan kesimpulan } \\
\text { yang telah mereka buat }\end{array}$ & 3,5 & $\mathrm{~B}$ & 4 & SB \\
\hline & C. Kegiatan Akhir & & & & \\
\hline III & \begin{tabular}{|l} 
19. Memberikan penghargaan kepada kelompok \\
terbaik
\end{tabular} & 2 & $\mathrm{C}$ & 3,5 & B \\
\hline & $\begin{array}{|lll|}\text { 20. Menyampaikan materi selanjutnya dan } \\
\text { mengucapkan salam }\end{array}$ & 3 & $\mathrm{~B}$ & 4 & SB \\
\hline & Jumlah & 55,5 & & 72,00 & \\
\hline & Rata-rata & 2,8 & & 3,61 & \\
\hline & & B & & SB & \\
\hline
\end{tabular}

Dari Tabel 4.2 tersebut, menunjukkan adanya peningkatan nilai rata-rata aktivitas guru dari siklus I menuju siklus II sebesar 0,7 dengan skor rata-rata aktivitas guru pada siklus I sebesar 2,8 mengalami peningkatan pada siklus II menjadi 3,61 .

\section{Pembahasan}

Pelaksanaan penelitian tindakan kelas dengan menggunkan model pembelajaran inkuiri terbimbing pada materi pokok cahaya dan alat optik terdiri dari dua siklus yaitu siklus I dan siklus II. Pelaksanaan pembelajarann ini bertujuan untuk meningkatkan keterampilan proses sains peserta didik kelas $\mathrm{VIII}_{\mathrm{A}} \mathrm{SMP}$ Negeri 1 Wawonii Utara sehingga memperoleh ketuntasan keterampian proses sains sebagai efek penerapan model pembelajaran inkuiri terbimbing.

Pada Siklus I dilaksanakan sesuai yang direncanakan yaitu dua kali pertemuan. Pertemuan pertama pada tanggal 4 Mei 2019 dan pertemuan kedua pada tanggal 8 Mei 2019. Pada pertemuan pertama yang dipelajari adalah sub materi pokok sifat-sifat cahaya dan pertemuan kedua sub materi pembentukan bayangan pada cermin.

\section{Keterampilan Proses Sains}

Berdasarkan hasil analisis deskriptif keterampilan proses sains peserta didik pada Tabel 4.1 menunjukkan bahwa aspek 
keterampilan proses sains peserta didik di siklus I sebesar 2.5 termasuk dalam kategori cukup. Dalam siklus I aspek keterampilan proses sains peserta didik seperti mengamati, merumuskan masalah, hipotesis, melakukan percobaan, menganalisis data menyimpulkan dan mengkomunikasikan hasil dalam kategori cukup sehingga semua aspek perlu ditingkatkan lagi. Rendahnya aspek-aspek tersebut dikarenakan peserta didik tidak terbiasa melakukan kegiatan praktikum secara langsung dan tidak terbiasa mengerjakan LKPD, dimana peserta didik harus merumuskan masalah, hipotesis dan melakukan percobaan. Selain itu, ada beberapa peserta didik yang kurang antusias dalam mengikuti kegiatan pembelajaran.

Adapun Solusi yang diupayakan yaitu guru harus berusaha membimbing peserta didik dalam melakukan percobaan secara rinci dan jelas. Selain itu, dalam mengerjakan LKPD guru harus menjelaskan tata cara pengisian LKPD Sehingga antara percobaan yang dilakukan dan mengerjakan LKPD bisa sejalan. Guru juga harus membuat suasana belajar lebih menyenangkan sehingga peserta didik yang kurang antusias menjadi lebih antusias dalam mengikuti kegiatan pembelajaran. Oleh karena itu, akan seimbang antara peserta didik yang antusias dan guru.

\section{Keterlaksanaan Model Pembelajaran Inkuiri Terbimbing}

Berdasarkan hasil analisis aktivitas guru yang termasuk dalam kategori cukup dengan skor rata-rata 2 yaitu aspek guru meminta peserta didik untuk mengajukan pertanyaan/merumuskan masalah, guru memberikan kesempatan kepada peserta didik dalam melakukan diskusi kelompok untuk menjawab LKPD, guru memberi kesempatan untuk memeriksa kembali jawaban LKPD dan membuktikan benar atau tidaknya hipotesis yang mereka ajukan, guru membimbing peserta didik untuk membuat kesimpulan bersama kelompoknya, guru bersama peserta didik mereview dan menyimpulkan materi yang telah dipelajari dan peserta didik antusias. Rendahnya aktivitas guru tersebut disebabkan guru masih dalam tahap penyesuaian diri untuk mengajar, sehingga ada beberapa aktivitas yang semesti nya dilakukan tatapi tidak dilaksanakan. Hal ini juga dipengaruhi oleh penggunaan waktu yang kurang optimal terutama pada proses melakukan kegiatan eksperimen dan diskusi kelompok untuk mengerjakan LKPD yang membutuhkan waktu lebih dari yang direncanakan sehingga kegiatan penutup pembelajaran menggunakan waktu yang minim hal ini menyebabkan dalam kegiatan guru memberi kesempatan untuk memeriksa kembali LKPD dan menyimpulkan hasil diskusi serta guru bersama peserta didik mereview serta materi yang telah dipelajari menjadi kurang optimal.

\section{Refleksi}

Dari masalah tersebut peneliti dan guru mata pelajaran melakukan analisis dan refleksi terhadap faktor-faktor yang menyebabkan kurangnya keterampilan proses sains peserta didik dan beberapa aspek aktivitas guru dalam proses pembelajaran, antara lain sebagai berikut:

1) Peserta didik kurang dalam merumuskan masalah untuk mengajukan pertanyaan.

2) Peserta didik kurang dalam merumuskan hipotesis.

3) Peserta didik kurang dalam menganalisis data.

4) Guru kurang memberikan kesempatan kepada peserta didik dalam melakukan diskusi kelompok untuk menjawab LKPD.

5) Guru kurang memberi kesempatan untuk memeriksa kembali jawaban LKPD dan membuktikan benar atau tidaknya hipotesis yang mereka ajukan tentang fenomena yang ditampilkan.

6) Guru kurang membimbing peserta didik untuk membuat kesimpulan bersama kelompoknya.

Selanjutnya peneliti bersama guru juga menentukan langkah-langkah perbaikan untuk siklus II, yaitu: 
1) Dengan guru memberikan bimbingan dan penjelasan tentang kegiatan pengamtan, peserta didik dapat merumuskan masalah.

2) Dengan guru memberikan bimbingan dan penjelasan tentang bagaimana merumuskan hipotesis yang baik, peserta didik dapat merumuskan hipotesis berdasarkan rumusan masalah yang telah dibuat.

3) Dengan guru memberikan penjelasan dan pemahaman mengenai cara mengerjakan atau menganalisis data, peserta didik dapat menyelesaikan analisis dengan tepat.

4) Guru hendaknya memberikan kesempatan kepada peserta didik dalam melakukan diskusi kelompok untuk menjawab LKPD.

5) Guru hendaknya memberi kesempatan untuk memeriksa kembali jawaban LKPD dan membuktikan benar atau tidaknya hipotesis yang mereka ajukan mengenai fenomena yang ditampilkan.

6) Guru hendaknya membimbing peserta didik untuk membuat kesimpulan bersama kelompoknya.

Berdasarkan hasil analisis dan refleksi diatas, guru akan melakukan beberapa perbaikan untuk diterapkan pada siklus II serta melibatkan peserta didik dalam setiap kegiatan pembelajaran sehingga meningkatkan daya pikir dan kemampuan peserta didik menemukan pemahamannya terhadap materi. Sehingga diharapkan pada pertemuan selanjutnya diperoleh peningkatan aktivitas guru dalam pembelajaran dan berdampak pada meningkatnya keterampilan proses sains.

\section{Siklus II}

Siklus II dilaksanakan dua kali pertemuan, yaitu tanggal 13 sampai 25 Mei 2019. Pada siklus ini proses pembelajaran berlangsung berdasarkan RPP ygang telah ditetapkan.

\section{Keterampian Proses Sains}

Berdasrkan hasil analisis deskriptif pada siklus II menunjukkan adanya peningkatan keterampilan proses sains peserta didik dari siklus I. Aspek-aspek keterampilan proses sains yang pada siklus I berada pada kategori cukup mengalami peningkatan yang lebih baik seperti yang terlihat pada Tabel 4.1 dengan perolehan skor rata-rata keterampilan proses sains sebesar 3 yang berada pada kategori baik. Hal ini menunjukan adanya peningkatan nilai rata-rata keterampilan proses sains peserta didik dari siklus I yang dapat dilihat pada Tabel 4.1. Adanya peningkatan nilai rata-rata peserta didik ini menunjukan bahwa peserta didik sudah mulai terbiasa dalam melakukan kegiatan eksperimen dan mengerjakan LKPD dengan model pembelajaran Inkuiri terbimbiing. Meskipun peninggkatan tidak berbeda jauh dengan nilai rata-rata sebelumnya namun, sudah mencapai nilai dalam kategori baik. dapat disimpulkan bahwa model pembelajaran inkuiri terbimbing berpengaruh signifikan terhadap nilai rata-rata aspek KPS. Hal ini diperkuat dengan hasil penelitian Sabahiyah dan Suastra (2013) yang menunjukkan bahwa model pembelajaran inkuiri terbimbing berpengaruh terhadap peningkatan KPS.

Pada siklus II semua aspek keterampilan proses sains peserta didik meningkat, peningkatan terlihat pada aspek keterampilan proses sains mengamati, aspek merumuskan masalah, aspek merumuskan hipotesis, aspek merencanakan percobaan/kegiatan diskusi, aspek melakukan percobaan/kegiatan diskusi, aspek menganalisis data, dan aspek menyimpulkan dan mengkomunikasikan itu dalam kategori yang cukup. Menurut peneliti peningkatan keterampilan proses sains peserta didik disebabkan peserta didik sudah mulai terbiasa mengerjakan LKPD sehingga sedikit demi sedikit memahami bagaimana mengerjakan LKPD berdasarkan hasil eksperimen atau kegiatan yang mereka lakukan, selain itu kegiatan eksperimen pada siklus I lebih sulit dibandingkan kegiatan eksperimen pada siklus II. Dimana pada siklus I peserta didik banyak melakukan kegiatan eksperimen seperti merangkai percobaan cermin dan lensa dan membuktikan sifat-sifat cahaya sementara pada 
siklus II peserta didik hanya melakukan satu kegiatan eksperimen dan selanjutnya non eksperimen dengan berdiskusi untuk mengumpulkan data-data melalui kehidupan sehari-hari mereka dan melalui bahan ajar yang mereka miliki. peningkatan KPS pada peserta didik tersebut selaras dengan penelitian yang dilakukan oleh Aksari (2012) yang menyatakan bahwa model pembelajaran inkuiri terbimbing mempengaruhi peningkatan KPS peserta didik.

\section{Keterlaksanaan Model Pembelajaran Inkuiri Terbimbing}

Pelaksanaan tindakan pada siklus II dilakukan dengan memperbaiki kekurangan pada siklus I, dimana beberapa aspek aktivitas guru yang kurang diperhatikan atau tidak dilaksanakan guru meminta peserta didik untuk mengajukan pertanyaan, guru memberikan kesempatan kepada peserta didik dalam melakukan diskusi kelompok untuk menjawab LKPD, guru memberi kesempatan untuk memeriksa kembali jawaban LKPD dan membuktikan benar atau tidaknya hipotesis yang mereka ajukan, guru membimbing peserta didik untuk membuat kesimpulan bersama kelompoknya, guru bersama peserta didik mereview dan menyimpulkan materi yang telah dipelajari pada siklus II begitupun dengan aktivitas guru yang sudah dilaksanakan pada siklus I tetap dipertahankan atau ditingkatkan pada siklus II. Pada siklus II menunjukan adanya peningkatan skor rata-rata aktivitas guru menjadi 3,61 dengan kategori sangat baik. Aspek-aspek aktivitas guru lainnya juga mengalami peningkatan yang dapat dilihat pada Tabel 4.2. Peningkatan rata-rata aktivitas guru menandakan bahwa kelemahan-kelemahan yang terdapat pada siklus I dapat teratasi sehingga guru perlu mempertahankan keterampilan dalam menggunakan model pembelajaran inkuiri terbimbing.

Temuan dalam penelitian ini memberikan informasi bahwa model pembelajaran inkuiri terbimbing memiliki keunggulan dalam hal meninggkatkan KPS siswa terhadap konsep sifat-sifat cahaya. Penelitian yang mendukung penelitian ini yaitu hasil penelitian Ambarsari et al. (2013) yang memperlihatkan bahwa penerapan pembelajaran inkuiri terbimbing memberikan pengaruh yang signifikan terhadap keterampilan proses sains dasar siswa.

\section{KESIMPULAN}

Berdasarkan rusmusan masalah dan hasil penelitian yang diperoleh, kesimpulan dari pelaksanaan penelitian tindakan kelas ini adalah sebagai berikut.

1. Keterampilan proses sains peserta didik kelas VIII $_{A}$ SMP Negeri 1 Wawonii Utara mata pelajaran IPA materi pokok cahaya dan alat optik dengan menggunakan model pembelajaran inkuiri terbimbing mengalami peningkatan sebesar 2.5 sedangkan pada siklus II diperoleh peningkatan sebesar 3 .

2. Aktivitas guru pada pembelajaran IPA kelas VIII $_{A}$ SMP Negerii 1 Wawonii Utara pada materi pokok cahaya dan alat optik yang diajarkan dengan menggunakan model pembelajaran inkuiri terbimbing mengalami peningkatan dimana pada siklus I nilai ratarata sebesar 2,9 sedangkan pada siklus II sebesar 3,61.

\section{DAFTAR PUSTAKA}

Ambarsari, W., Santoso, S., dan Maridi, M. (2013). Penerapan Pembelajaran Inkuri Terbimbing Terhadap Keterampilan Proses Sains Dasar pada Pembelajaran Biologi Siswa Kelas VIII SMP Negeri 7 Surakarta. Jurnal Pendidian Biologi, 5(1), 81-95.

Anderson, L.W. \& Krathwohl, D. R., 2010. Kerangka Landasan Untuk Pembelajaran, Pengajaran dan Asesmen Revisi Taksonomi Pendidikan Bloom. Jogjakarta: Pustaka Pelajar.

Atmowidjoyo, Sutarjo. (2007). Landasan Kependidikan Prinsip-Prinsip Dasar Teori 
Belajar dan Konsep Intruksional. Jakarta: Universitas Islam Jakarta.

Dahar R.W.,(1996). Teori- teori Belajar. Bandung: Erlangga.

Dewi, N. L. I., dkk. Penerapan Model Pembelajaran Inkuiri Terbimbing untuk Meningkatkan Keterampilan Akuisisi Fisika pada Siswa Kelas X SMA Negeri 5 Palu. Universitas Tadulako: Sulawesi Tengah.

E. Mulyasa. (2005). Menjadi Guru Profesional Menciptakan Pembelajaran Kreatif dan Menyenagkan. Bandung: Remaja Rosdakarya.

Hamalik, Oemar. (2003). Kurikulum dan Pembelajaran. Jakarta: PT. Bumi Aksara

Hofstein, Avi and Lunetta. Vincent N. (1982). The Role of Laboratory in Science Teaching: Negleted Aspect of Research. Dalam Review of Educational Research. Vol 52 (2). 7 halaman.

Haspari, A. D., dkk. 2017. Penerapan Pembelajaran Fisika dengan Inkuiri Terbimbing untuk Meningkatkan Hasil Belajar Kognitif. Universitas PGRI Madiun: Madiun

Indrayanthi, A. A. S. D. 2012. Pengaruh Penerapan Model Siklus Belajar Terhadap Pemahaman Konsep Fisika dan Keterampilan Berpikir Kritis Siswa. Journal Penelitian Pascasarjana UNDIKSHA, Vol. 2 No.1.

Juhji. 2016. Peningkatan Keterampilan Proses Sains Siswa Melalui Pendekatan Inkuiri Terbimbing. UIN Sultan Maulana Hasanuddin: Serang. http://pasca.undiksha.ac.id/ejournal/index.php/jurnal_ipa/article/view/3 96

Maulidati, R., Yusrizal, dan Mursal, M. (2015). Penerapan Metode Pembelajaran Inkuiri Terbimbing Untuk Meningkatkan Pemahaman Konsep Dan Keterampian Berpikir Kritis Siswa SMP Pada Materi
Cahaya. Jurnal Pendidikan Sains Indonesia, 3(2), 71-84.

McBride, J.W. et al. (2004). Using an inquiry approach to teach science to secondary school science teachers. IOP Publishing LTD. Dalam Physics Education [Online], $\begin{array}{lllll}\text { Vol } & 39 & \text { (5), } & 6 & \text { halaman. }\end{array}$ www.iop.org/journals/physed september 2012]

Purwanto, N. 2010. Prinsip-prinsip dan Teknik Evaluasi Pengajaran. Bandung: PT Remaja Rosdakarya

Puspita, A. T., \& Jatmiko, B. (2013). Implementasi Model Pembelajaran Inkuiri Terbimbing (Guided Inquiry) Terhadap Keterampilan Berpikir Kritis Siswa Pada Pembelajaran Fisika Materi Fluida Statis Kelas XI di SMA Negeri 2 Sidoarjo. Inovasi Pendidikan Fisika, 2(3).

Rahmani, R., Halim, A., dan Jalil, Z. (2016). Penerapan Model Pembelajaran Inkuiri Terbimbing Untuk Meningkatkan Keterampilan Proses Sains (KPS) Siswa Sekolah Dasar. Jurnal Pencerahan, 10(2).

Roestiyah, N.K. (2008). Stategi Belajar Mengajar. Jakarta: Rineka Cipta.

Rusche, S.N and Jason K. (2011). "You have to absorb Yourself in it": Using Inquiry and Reflection to Promote Student Learning and Self Knowladge. Dalam Amerian Sociology Asociation. Vol 39. (http://ts.sagepub.com [25 April 2012]

Sakdiah, dkk. 2018. Penerapan Model Inkuiri Terbimbing untuk Meningkatkan Pemahaman Konsep dan Kps pada Materi Listrik Dinamis Siswa SMP. Universitas Kuala Banda Aceh: Aceh.

Semiawan, CA, Tahyong, F, Belen, S, Matahaemual, Y, dan Suseloardjo, W. 1992. Pendekatan Keterampilan Proses. Jakarta: Gramedia.

Sukma, dkk. 2016. Pengaruh Model Pembelajaran Inkuiri Terbimbing (Guided Inquiry) dan Motivasi Terhadap Hasil 
Belajar Fisika Siswa. Universitas Mulawarman: Samarinda.

Suryosubroto, B. (2009). Proses Belajar Mengajar di Sekolah. Jakarta: PT. Rineka Cipta.

Tangkas, I M. (2012). Pengaruh Implementasi Model Pembelajaran Inkuiri Terbimbing Terhadap Kemampuan Pemahaman Konsep Dan Keterampilan Proses Sains Siswa
Kelas X SMAN 3 Amlapura. Jurnal Pendidikan dan Pembelajaran IPA Indonesia, 2(1).

Towndrow, P.A. et al. ( 2008). Promoting Inquiry Through Science Reflective Journal Writing. Dalam Eurasia Journal of Mathematics, Science \& Technologi Education.Vol 4(3). 5 halaman. www.ejmste.com [3 Maret 2012] 